\title{
MIĘDZYNARODOWA KONFERENCJA PT. „SZLAKI MIĘDZYMORZA: BAŁTYK-BUG-BOH-PONT (OD III DO POŁOWY I TYSIĄCLECIA PRZED CHR.)", OBRZYCKO, 13-16 PAŹDZIERNIKA 2008 R.
}

W ramach cyklu spotkań dotyczących problematyki pogranicza biokulturowego wschodu i zachodu Europy, organizowanych przez Instytut Prahistorii, Instytut Wschodni oraz Fundację Uniwersytetu im. Adama Mickiewicza w Poznaniu, odbyła się w dniach 13-16 października 2008 r. w Domu Pracy Twórczej w Obrzycku, międzynarodowa konferencja „Szlaki Międzymorza: Bałtyk-Bug-Boh-Pont (od III do połowy I tysiąclecia przed Chr.)”.

W Komitecie Honorowym zasiedli: Jego Magnificencja prof. dr hab. Bronisław Marciniak - rektor Uniwersytetu im. Adama Mickiewicza, prof. dr hab. Hanna Kóčka-Krenz - dziekan Wydziału Historycznego UAM, prof. dr hab. Danuta Minta-Tworzowska - dyrektor Instytutu Prahistorii UAM, prof. dr hab. Krzysztof Pietkiewicz dyrektor Instytutu Wschodniego UAM oraz mgr Hanna Szafrańska - dyrektor Fundacji UAM w Poznaniu. W skład Komitetu Organizacyjnego weszli: prof. dr hab. Aleksander Kośko, prof. dr hab. Marzena Szmyt, dr Marcin Ignaczak i mgr Paulina Suchowska.

Problematyka konferencji dotycząca szlaków tranzytowych (dalekosiężnych i interregionalnych) jest pokłosiem dyskusji podejmowanej w ostatnich latach w kręgu środowisk identyfikowanych z inicjatywami edytorskimi „Baltic-Pontic Studies” i „Archaeologia Bimaris", dotyczącej mechanizmów obiegu wzorców kulturowych w strefie pogranicza wschodu i zachodu Europy.

Do uczestnictwa w konferencji zaproszeni zostali naukowcy z Białorusi, Polski i Ukrainy, którzy zaprezentowali swoje referaty w ramach pięciu sesji, każdorazowo zamykanych dyskusją. Łącznie przez trzy dni trwania obrad uczestnicy i goście (blisko 50 osób) wysłuchali 24 referatów. Odbyła się też sesja posterowa.

Konferencję rozpoczęło przemówienie prof. dr hab. Danuty Minty-Tworzowskiej, podkreślające ważność problematyki będącej wątkiem przewodnim wzmiankowanego „obrzyckiego spotkania” badaczy i naukowców. Głos zabrała również mgr Hanna Szafrańska, akcentując rolę archeologii w wyznaczaniu nowych pól dyskusji nad kontaktami interegionalnymi i zwracając uwagę na jej ponadczasowy wymiar. Ponadto tytułem wstępu, zarys problematyki badawczej konferencji (,Szlaki tranzytowe bałtycko-pontyjskiego Międzymorza, wczesne etapy rozwoju: III - połowa I tysiąclecia BC"), przedstawili: prof. dr hab. W. Kloczko oraz prof. dr hab. A. Kośko. W tej części odbyła się również sesja posterowa dr. J. Roli, który zaprezentował późnoneolityczne drogi przepraw przez dolinę Noteci, na przykładzie Żuławki Małej. 
W pierwszej części obrad, zatytułowanej „Kontekst środowiskowy (»szlaki naturalne«): dane paleobotaniczne”, dotyczącej aspektów środowiskowych i możliwości identyfikacji szlaków (szlakowości) w pradziejach na podstawie badań paleogeograficznych oraz metodami teledetekcyjnymi referaty wygłosili dr M. Makohonienko oraz prof. dr hab. W. Rączkowski.

Druga część spotkania dotyczyła kontekstu historycznego oraz doświadczenia techniczno-organizacyjnego szlaków śródlądowych doby starożytności i średniowiecza (poświadczenia źródłowe, interpretacje: modele funkcjonowania). Tu swoje referaty zaprezentowali: dr W. Tyborowski, mgr J. Cieszewska oraz prof. dr hab. K. Pietkiewicz.

W części trzeciej, zatytułowanej: „Generatory bałtycko-pontyjskich szlaków: surowce zakres przestrzenny, etapy aplikacji w kulturach międzymorza (III - połowa I tysiąclecia przed Chr.)" znalazło się miejsce na empiryczne poświadczenia kontaktów, poprzez wymiar surowcowy. W tym segmencie konferencji referaty przedstawili: dr P. Chachlikowski, który podjął tematykę identyfikacji i recepcji bazaltu wołyńskiego; prof. dr hab. J. Czebreszuk, koncentrujący się na wschodnioeuropejskich drogach rozprzestrzeniania bursztynu, oraz dr J. M. Brovender, interpretujący kwestię metalurgii miedzi na Ukrainie.

W czwartej sesji podniesiono tematykę materialno-przedmiotowych dowodów szlaku bądź szlaków „Bałtyk-Bug-Boh-Pont” z punktu widzenia interpretacji kulturoznawczo-historycznej. Referaty w tej części zaprezentowali: prof. dr hab. M. Szmyt; prof. dr hab. J. Machnik; dr K. P. Bunjatian; prof. dr hab. J. Libera wraz z mgr. J. Sobierajem i dr. V. Konoplą. W dalszej części sesji referaty przedstawili: prof. dr hab. W. Kloczko wraz z prof. dr. hab. A. Kośko, na zakończenie zaś dr dr P. Makarowicz, K. Ślusarska, S. D. Lysenko, S. S. Lysenko oraz M. Ignaczak.

Sesja piąta, niejako podsumowująca konferencję, dotyczyła perspektywy szlaków Międzymorza jako długofalowego programu badawczego. W tej części referaty zaprezentowali: prof. W. W. Otroszczenko, który podjął tematykę szlaków i połączeń na terenach Ukrainy w epoce brązu; dr M. Krywalcewicz koncentrujący się na systemie szlaków komunikacyjnych w Białorusi w III i początkach II tysiąclecia BC. Inspirujące było także wystąpienie prof. dr hab. S. Czopka, traktujący o roli szlaku Dniestr-San w epoce brązu i wczesnej epoce żelaza (z powodu nieobecności autora referat został odczytany).

Całości konferencji dopełniła dyskusja generalna nad najbardziej inspirującymi poznawczo zagadnieniami poruszanymi w poszczególnych referatach. Podjęto w niej próbę zarysowania najważniejszych potrzeb i postulatów badawczych, wskazujących na konieczność kontynuacji badań, również interdyscyplinarnych, nad tematyką szlakowości w pradziejach. Podkreślono konieczność dalszych studiów, także na podstawie nowych danych, głównie lingwistycznych i hydrologicznych, których z przyczyn niezależnych od organizatorów nie udało się umieścić w programie konferencji.

Paulina Suchowska-Ducke, Marcin Ignaczak Instytut Prahistorii, Uniwersytet im. Adama Mickiewicza ul. Św. Marcin 78, 61-809 Poznań, Poland 